\title{
RESENHAS
}

\section{Locais de Crime: dos vestígios à dinÂMica Criminosa, de Jesus Antonio Velho et $A$ L. Campinas: Millennium Editora, 2013, 574 PP.}

\begin{abstract}
Nas Ciências Forenses há um entrelaçamento único de ciências e leis, envolvidas em um desafio constante para dar suporte a decisões corretas e elaboração de novas leis, que possam atender à demanda de uma sociedade justa. Esta dinâmica exige que os profissionais dedicados às Ciências Forenses estejam aptos a adaptar novos métodos de análise, alterar protocolos e aplicar conhecimentos científicos de diferentes áreas, atuando na fronteira do conhecimento. A fotografia de capa do livro, simulando um local de crime, já indica a complexidade de uma investigação forense, que envolve a busca minuciosa de vestígios criminais, com a utilização de técnicas específicas que exigem uma formação profissional multidisciplinar, para elucidação das causas e possíveis envolvidos em um crime.
\end{abstract}

O rigor da pesquisa pode dar pistas da realidade de fatos jamais imaginados, com respostas, quase sempre, complexas. As Ciências Forenses representam uma área profissional empolgante, multidisciplinar, com um conjunto quase ilimitado de desafios para serem enfrentados.

A investigação de uma ocorrência criminal começa no final da história, por exemplo, após um homicídio. Em muitos casos, as informações sobre o último evento e o evento inicial podem até ser razoavelmente bem conhecidas, porém, as informações sobre o que ocorreu entre estes pontos, são muitas vezes obscuras e contraditórias.

Locais de Crime - dos vestígios à dinâmica criminosa representa uma obra abrangente e muito detalhada, com fotos e figuras bem selecionadas, didaticamente apresentadas ao longo do texto, para ilustrar um dos principais aspectos do estudo da criminalística: o local onde ocorreu o crime ou outros locais onde vestígios tenham sido encontrados. Esta compreende uma área a partir da qual a maior parte das provas físicas ou periciais podem ser resgatadas pelo perito criminal.

A confecção do livro foi coordenada pelos peritos criminais federais Jesus Antonio Velho, Karina Alves Costa e Clayton Tadeu Mota Damasceno, todos com formação multidisciplinar e experiência na investigação de locais de crime. Os autores têm ampla experiência didática, uma vez 
que ministram conteúdos desta área em cursos de formação e atualização de peritos oficiais, além de cursos universitários que buscam a carreira na área forense. Importante ressaltar, que a estruturação do livro foi enriquecida pela participação de outros autores, especialistas destacados das mais diversas áreas, tais como: entomologia forense, geologia forense, genética forense, química forense, medicina legal, dentre outras. Somada a essa multidisciplinaridade tão necessária na área de investigação em locais de crime, os autores advém de diferentes esferas institucionais: além de peritos oficiais federais e estaduais, houve a participação de docentes e membros do meio acadêmico, enriquecendo o intercâmbio de informações, fator fundamental na aplicação do conhecimento na área de Ciências Forenses.

Locais de Crime: dos vestígios à dinâmica criminosa apresenta de maneira sistematizada e muito didática, definições de termos e subsídios periciais relacionados a estratégias de reconhecimento, busca, análises e interpretações de vestígios, finalizando com situações de reprodução simulada de locais de crime. Os autores ainda abordam a perícia em locais de desastre de massa, extremamente importante para contribuir na busca de vestígios para a identificação de vítimas e elucidação da causa do desastre.

O livro está dividido em 4 partes, totalizando 17 capítulos que abordam aspectos importantes para o entendimento e realização de uma perícia criminal minuciosa em locais de crime.

$\mathrm{Na}$ Parte 1 - Preservação e documentação de locais de crime (capítulos 1, 2 e 3) são apresentadas definições e informações sobre crimes, locais de crime, busca de vestígios, e cuidados necessários para o estabelecimento da cadeia de custódia. São abordados aspectos relacionados à importância do isolamento e preservação de um local de crime bem como as responsabilidades dos profissionais envolvidos na manutenção da integridade do local, com recomendações para a atuação pericial na abordagem do local de crime, na busca dos vestígios e no seu registro.

$\mathrm{Na}$ Parte 2 - Os principais tipos de vestigios (capítulos 4, 5, 6, 7, 8 e 9) os autores discorrem sobre vestígios biológicos, fontes de DNA, e a identificação e coleta de diferentes fluidos corpóreos (sangue, saliva, sêmen), pêlos e até vestígios presentes no próprio cadáver. São apresentados também conteúdos relacionados ao estudo de vestígios entomológicos, morfológicos, químicos, físicos e microvestígios. 
Na Parte 3 - Reconstruindo a dinâmica sob a ótica dos vestígios (capítulos 10, 11, 12, 13 e 14) são discutidas análises de locais de crime envolvendo disparos de arma de fogo e manchas de sangue. Nos casos com vítimas fatais, são descritos os exames externos do cadáver, desde sua identificação até a descrição de lesões e causas jurídicas da morte. Ao final, são apresentadas análises de casos reais, onde o leitor é convidado a fazer o caminho inverso: primeiramente é apresentada a dinâmica e conclusão do caso em estudo e, a seguir, elenca-se os principais vestígios que deram fundamentação às conclusões inicialmente apresentadas.

Na Parte 4 - A elaboração do laudo e condições especiais de atuação do perito de locais (capítulos 15, 16 e 17) é detalhada a elaboração e a estrutura de um laudo de local, o planejamento e execução de uma reprodução simulada e por fim, a perícia em locais de desastres em massa envolvendo o conceito e classificação de desastre em massa, e as estratégias, técnicas e dificuldades para a busca, recuperação e principalmente identificação de vítimas.

Ao final de cada capítulo, há um resumo do seu conteúdo seguido de questões sobre o tema tratado. Esse formato proporciona ao leitor maior dinâmica no entendimento e fixação do assunto do capítulo, bem como propicia uma forma objetiva de avaliar o conhecimento transmitido, podendo ainda despertar novos questionamentos, incentivando o leitor a buscar informações que possam complementar a aprendizagem, por meio da consulta às referências bibliográficas apresentadas ou em outras fontes de consulta.

Certamente, esta obra representa uma grande contribuição para a formação de profissionais nas Ciências Forenses e pode mesmo ser utilizada como uma fonte de consulta durante perícias em locais de crime, pois oferece subsídios científicos para estudantes, peritos oficiais, e para outros profissionais que militam ou têm interesse na área da investigação forense.

BRUno SPINOSA DE MARTINis Doutor em Química. Professor Associado da USP. Coordenador do Laboratório de Análises Toxicológicas Forenses. Presidente da Sociedade Brasileira de Ciências Forenses.

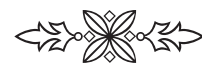

